\title{
GONADOTROPIN RELEASING HORMONE ANTAGONIST
}

\section{TREATMENT INDUCES CELL CYCLE ARREST IN GONADAL SOMATIC CELL AND ADRENOCORTICAL TUMORS}

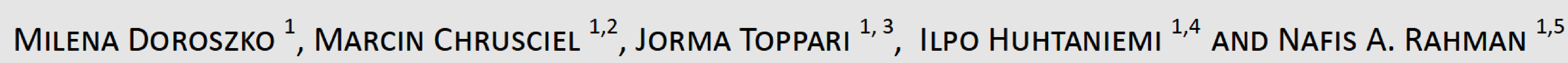

1) Department of Physiology, Institute of Biomedicine, University of Turku, Finland; 2) Institute of Animal Reproduction and Food Research, Polish Academy of Sciences, Olsztyn, Poland; 3 ) Department of Pediatrics, University of Turku; 4 ) Department of Surgery and Cancer, Faculty of Medicine, Imperial College London, London, U.K.; 5) Department of Reproduction and Gynecological Endocrinology, Medical University of Bialystok, Poland

\section{BACKGROUND}

G-coupled protein receptors in tumor tissues have been successfully used as potential targets for cancer therapies. In this study, we used transgenic mice carrying SV40 T-antigen under the inhibin alpha $6 \mathrm{~kb}$ promoter (inha/Tag) that develop granulosa/ Leydig cell tumors by the age of 6-months. Prepubertal gonadectomy results in adrenocortical tumors $5 \mathrm{mo}$ after castration. Their gonadal/adrenal tumors and tumor-derived cell lines: BLT1 (Leydig), KK1 (granulosa), Calpha1 (adrenocortical) express gonadotropin releasing hormone (GnRHR) and luteinizing hormone receptors (LHCGR). Earlier, we have shown that chemical (by GnRH

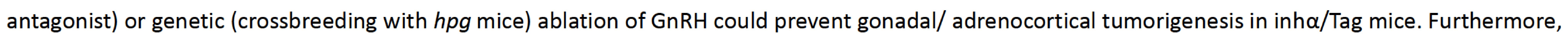
GnRH antagonist treatment blocked the adrenocortical tumor progression in these mice. Hereby, we studied GnRH antagonist Cetrorelix acetate (CTX) induced mechanism of tumor suppression in gonadal and adrenocortical tumors in vitro and in vivo.

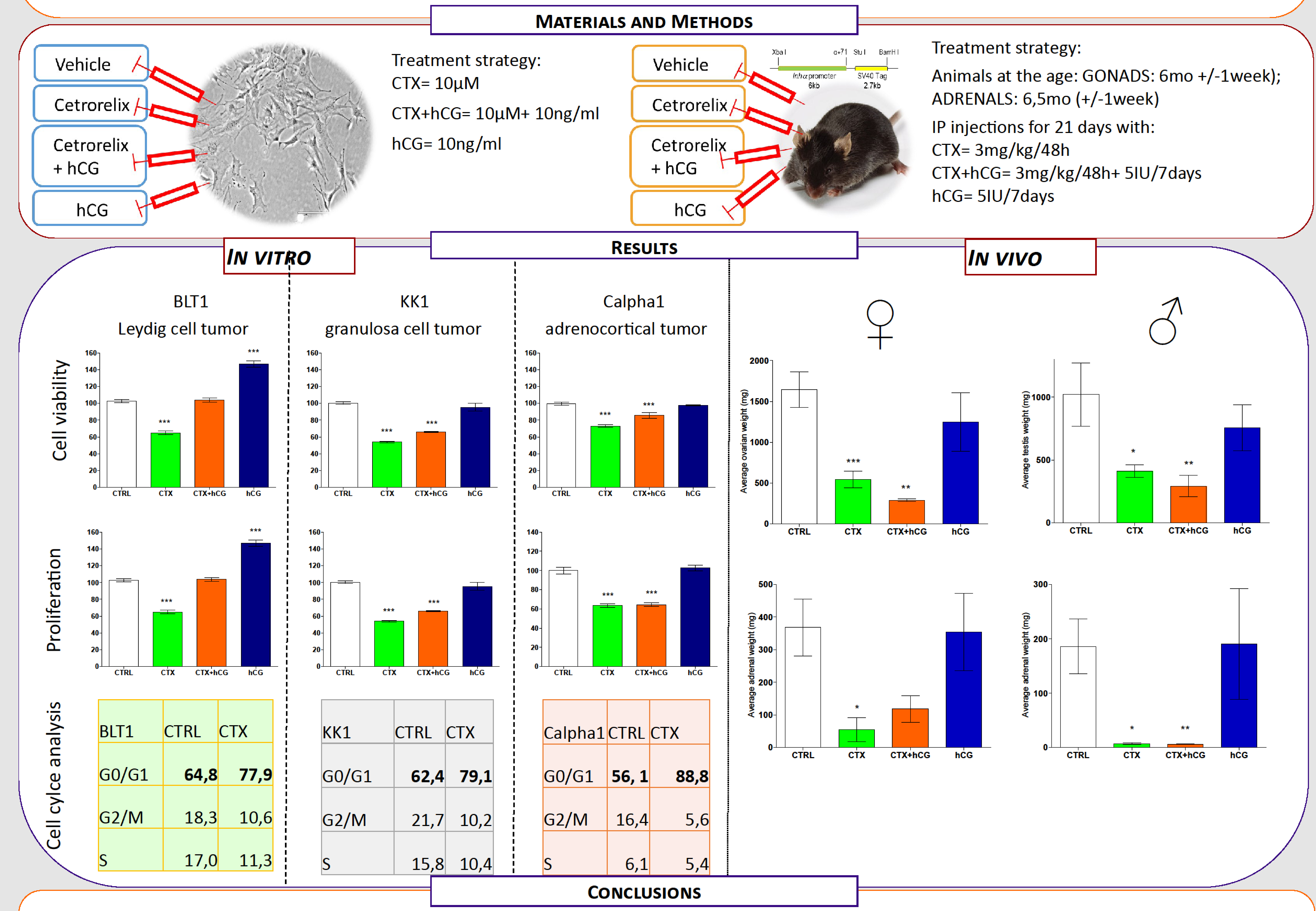

1. GnRH antagonist Cetrorelix acetate (CTX) treatment induced cell cycle arrest in G0/G1 phase, resulting in significantly decreased cell viability and proliferation in all the studied tumor cell types vs. vehicle.

2. Treatment with human chorionic gonadotropin (hCG) without or with CTX, did not affect the gonadal somatic/adrenocortical tumor progression in inha/Tag mice.

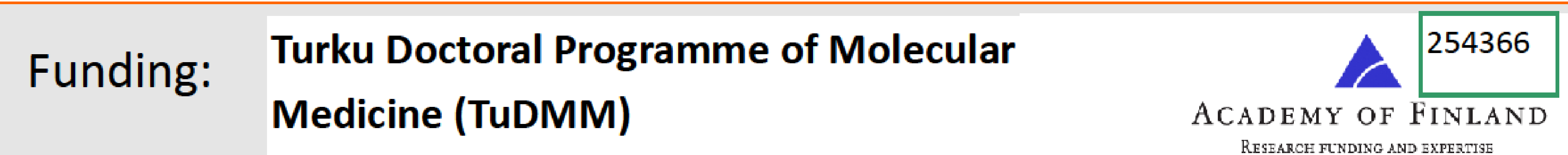

